\title{
The Impact of Barriers on Export Behavior of a Developing Country Firms: Evidence from Tanzania
}

\author{
Mursali. A. Milanzi \\ Faculty of Economics and Social Sciences, University of Agder \\ Service Box 422, Kristiansand N-4630, Norway \\ E-mail: mursali.a.milanzi@uia.no
}

\author{
Received: October 15, 2011 \\ Accepted: November 14, 2011 \\ Published: February 1, 2012 \\ doi:10.5539/ijbm.v7n3p10 \\ URL: http://dx.doi.org/10.5539/ijbm.v7n3p10
}

\begin{abstract}
The purpose of this paper is to identify main export barriers and to test empirically their impact on export behavior. A survey of 122 manufacturing firms was conducted in Tanzania between October 2008 and February 2009. The survey data were analyzed using factor analysis and the Tobit regression model. Factor analysis identified five significant barrier factors: lack of export market knowledge and information, export supply capacity constraints, inadequate export financing, inefficient regulatory framework, and poor infrastructure. The impact of the barriers on export behavior was then tested using the Tobit regression model. The results of the Tobit estimation indicated that the lack of export knowledge and information, limited finance, and poor infrastructure significantly affect export behavior. Interestingly, the significant barriers have had a disproportionate effect on the probability of exporting and the level of export intensity. Finally, the paper concludes and discusses the implications of the findings for policy, practices, and research.
\end{abstract}

Keywords: Exporting barriers, Export behavior, Tobit model, Developing country

\section{Introduction}

Export as an important economic activity to a firm and a driver of economic development of a nation has widely been acknowledged. In spite of numerous benefits of exporting, most firms do not export despite exporting being considered as inevitable in the increasingly integrated world markets (Pinho \& Martins, 2010). This is even more so for developing countries and for Tanzanian firms in particular. For example, studies conducted in sub-Saharan Africa that included firms from Tanzania indicate that a few firms export, selling only a small proportion of outputs abroad (van Biesebroeck, 2005; Rankin, Soderbom \& Teal, 2006; Milner \&Tandrayen, 2007). The explanation behind low export involvement has been that developing country firms encounter a multitude of barriers that vary in strength in attempting to initiate and/or expand export activities (Ghauri, Lutz \& Tesfom, 2003). However, there is a lacuna of knowledge regarding the extent to which export barriers hinder export involvement.

Earlier studies have documented various export barriers affecting export behavior of firms. There are studies describing the structure and nature of exporting barriers, and eventually categorizing them into a common origin. Most of these studies tend to categorize barriers as internal and/or external to the firms (Leonidou, 2004). Internal barriers are the controllable constraints emanating within the firms whereas external barriers emanate outside the firms' environment. Other studies tend to combine the assessment of export barriers with a range of organizational and export competitiveness issues purposely to elucidate why some firms perceive some barriers more strongly than others.

Despite previous studies providing insightful analyses and useful knowledge, this study contributes the following to the existing research knowledge. Firstly, the majority of the studies have so far been conducted in developed economies. Generalizing the existing findings in a developing economy setting would be misguided given a sharp contrast in institutional development between developed and developing economies (Wright, et al., 2005). Therefore, a comprehensive study like the current one is certainly a timely response. Secondly, despite export barrier studies being in plenty, there is a paucity of studies that systematically estimate and test the extent that such barriers affect export behavior. Thirdly, previous studies have produced inconsistent findings mainly due to 
weak methodologies (Arteaga-Ortiz \& Fernandez-Ortiz, 2010). Building on previous studies, a multivariate technique is introduced so as to identify significant barriers and assess their strength in influencing export behavior. Therefore, this is one of the few studies that estimates and assesses the strength of the effect of barriers on the likelihood of exporting and on the level of export intensity.

The remaining sections are organized as follows. Section two briefly describes the context and rationale of the study, followed by a review of literature in section three. A description of the methodology, and an analysis and a discussion of the findings are presented in sections four and five, respectively. Finally, the study concludes by highlighting both the contribution and the implications of the study's findings for policy, practice and research in section six.

\section{Study Context}

The United Republic of Tanzania has a total surface area of 945,087 square kilometers, and an estimated population of 38.2 million people, which grows at about 2.9 percent annually (United Republic of Tanzania URT, 2008). The agricultural sector is the mainstay of the Tanzanian economy, contributing more than 50 percent GDP, employment and merchandise exports. The manufacturing sector, which is largely agro-based, is relatively small and has a strong domestic market orientation. Nonetheless, given the vast natural resources, the manufacturing sector has an immense potential for growth. Tanzania is considered as one of Africa's best economic performers, having sustained an average real GDP growth of 7.0 percent between 2000 and 2007 (URT, 2008). Yet, the country is one of the least developed due to its low per capita income, high mortality rates, poor provision of social services, and many cases of HIV/AIDS.

Tanzania, like other developing countries, adopted market based policies in the 1980s, in order to improve its economic performance. To improve export performance, the country had to abolish export taxes and export licenses as well as to relax export prices and foreign exchange restrictions (Bigsten \& Danielson, 2001). Other measures include export retention, export guarantee and duty draw-back schemes. Moreover, Tanzania has subscribed to a number of preferential trade arrangements and treaties in order to have a fair access to foreign market opportunities. These include the East African Community (EAC), the Southern African Development Community (SADC), the African Growth and Opportunity Act (AGOA), the Economic Commission for Africa (ECA), the New Partnership for Africa's Development (NEPAD), the Technical Cooperation among Developing Countries (TCDC), and the World Trade Organization (WTO) (URT, 2008).

While macroeconomic reforms have greatly changed the business environment, export performance remains elusive. Persistent trade balance deficit that the country experiences (URT, 2008) is a clear manifestation of the failure by its firms to exploit opportunities presented by globalization. Thus, a comprehensive and a rigorous study to identify critical barriers to export participation is important in order to assist policy makers and managers in devising strategies and programs for promoting exports.

\section{Literature Review and Hypotheses}

Export barriers are understood as the internal and external constraints that dissuade firms from initiating and/or expanding export activities (Leonidou, 2004). Export barriers are found in many forms and are subject to different categorization. However, most barriers fall under the following dimensions: lack of knowledge and information, lack of strategic resources to undertake export operations, and exogenous barriers (Arteaga-Ortiz \& Fernandez-Ortiz, 2010). Below is a review of literature on the various kinds of barriers which eventually makes the basis for hypothesis development.

\subsection{Knowledge and Informational Barriers}

Export knowledge and informational barriers are associated with unfamiliarity with important aspects of export activities and export market environments. The barriers are found in several dimensions. They can be a result of difficulties in identifying export opportunities (Pinho \& Martins, 2010), a lack of understanding of foreign culture and business practices (Blomstermo, Eriksson \& Sharma, 2004), or the lack of knowledge on the availability of export support programs (Naidu \& Rao, 1993). Others are in the form of limited information to locate and analyze markets and inability to communicate with potential overseas customers (OECD, 2009).

Export knowledge and information barriers are particularly salient in Tanzania due to two main reasons. First, the market for information in Tanzania is underdeveloped because the institutions providing export market information or facilitating its acquisition are inadequate and/or inefficient (URT, 2003). Second, the majority of firms in Tanzania are small to medium (Confederation of Tanzania Industries - CTI, 2003). Hence, they lack other resources required to invest in knowledge and information generation activities such as research and development (R \& D) and, information and communication technologies. Based on this evidence and experience 
elsewhere (see Leonidou, 2004; OECD, 2009), it is reasonable to suggest that the lack of export knowledge and information will negatively affect export behavior of Tanzanian firms. This leads to the formulation of the following hypothesis:

Hypothesis 1: All else being equal, there will be a negative relation between a lack of export knowledge and information, and firms' export behavior.

\subsection{Strategic Resource Barriers}

Strategic resource barriers take different shapes and forms, ranging from lack of managerial and financial resources to a lack of capabilities to undertake export operations. Managerial barriers include insufficient human resource capacity to carry out export operations. In order to succeed internationally, firms need managers who are capable of identifying export opportunities, designing and implementing export marketing strategies, and monitoring business with overseas customers, as well as handling export documentation and logistics (Katsikeas, Leonidou \& Morgan, 2000). Thus, the lack of export oriented managers such as those with low export commitments (Pinho \& Martins, 2010), as well as those with limited export knowledge, skills, time, and with unrealistic exporting fears (Julian \& Ahmed, 2005; OECD, 2009) can negatively affect export behavior and performance of a firm.

Similarly, achieving superior export performance requires a sound financial position. Sufficient amount of financial resources enables firms to meet operational costs such as the costs of market research, transport, insurance (Leonidou, 2004). Sufficient financial liquidity position is required for firms to be able to manage financial risks associated with currency volatility and non-compliance by foreign customers (Ling-yee \& Ogunmokun, 2001; Uexkull, 2006). Thus, a shortage of working capital to finance exports (OECD, 2009), and/or inadequate access to export financing (da Silva \& da Rocha, 2001) can be critical to export behavior of a firm.

The lack of strategic resources in developing economies, such as Tanzania, seems to be a critical problem. The fact that the majority of Tanzanian firms are unable to invest in better technologies, meet international market demand requirements (e.g. quality and design) as well as to set competitive prices for the products (URT, 2003) suggests that lack of strategic resources is a critical problem. Furthermore, due to the underdeveloped financial markets, credit constraint is more pronounced (Anderson, 2011). This leads to the formulation of the following hypothesis:

Hypothesis 2: All else being equal, there will be a negative relation between a lack of strategic resources and firms' export behavior.

\subsection{Exogenous Barriers}

Exogenous barriers emanate outside the firms' environment, primarily due to the activities of other agents such as customers, suppliers, competitors and governments. Exogenous barriers are associated with the nature of the industry, home and foreign markets in which firms operate. By their very nature, exogenous barriers occur rapidly and often very difficult to predict and control (Leonidou, 2004). An example of industrial related barriers is strong competition from other firms in the domestic or foreign markets. Strong competition has the potential to drive less competitive firms out of markets. Naturally, the markets where competition is perceived to be particularly strong, firms that fear for competition are less likely to enter.

The home market environment can be a source of many barriers. In developing economies, governments' involvement in export activities in the form of regulations is high, thus, regulatory barriers tend to dominate. For example, stringent export procedures (da Silva \& da Rocha, 2001), and inadequate export assistance in terms of tax incentives and technical assistances (Julian \& Ahmed, 2005) have been cited as critical regulatory barriers. Other barriers include customs regulations (World Bank, 2004), poor infrastructure and corrupt practices among government officials (Okpara \& Koumbiadis, 2009).

Foreign market barriers are primarily associated with lack of understanding of economic, political, legal and socio-cultural environment in foreign markets (Leonidou, 2004). Critical foreign market barriers are in the form of tariff and non-tariff barriers (Korneliussen \& Blasius, 2008), political instability and strong competition in the overseas markets (da Silva \& da Rocha, 2001). The nature and strength of foreign market barriers may vary from one country to country, and from time to time. While some barriers can be debilitated through experiential knowledge, others such as exchange rate volatility and political instability are much harder to predict and overcome (Leonidou, 2004). As a result, some exogenous barriers tend to pose greater challenges to internationalization than others.

A good state of infrastructure is also important for export success. The main contention being that some locations offer better international market access and better production services than other locations. For 
example, locations with poor transport tend to have high transport costs, hence, inhibiting firms from participation in global production networks (Limao \& Venables, 2001). Similarly, Okpara and Koumbiadis (2009) indicate that firms located in areas where utility services (e.g. electricity and ICT) are poor and unreliable are likely to experience high costs of production and communication.

In conclusion, favorable home regulatory environment can help firms build capability to overcome foreign based barriers. This is because most firms tend to develop competence before exploiting such competences abroad. Apparently, however, business supporting environment in Tanzania is inefficient, making it the source of most export barriers (World Bank, 2004). Against the above backdrop, the following hypothesis is formulated:

Hypothesis 3: All else being equal, there will be a negative relation between the perceived strength of exogenous barriers and firms' export behavior.

\section{Data and Methodology}

A data set used in the analysis was obtained from a survey of manufacturing firms conducted in Tanzania between October 2008 and February 2009 in three cities: Dar es Salaam, Mwanza and Morogoro. The cities chosen have relatively many manufacturing establishments as well as registered manufacturing exporters (Marandu, 2008). The study constructed a sampling frame of 250 based on the directories of firms obtained from the Board of External Trade and Business Associations. The fact that Tanzania lacks comprehensive, reliable, and up-to-date data base of exporting firms (Marandu, 2008), it was necessary to collect and thoroughly review various sources of firm listings so as to widen the chance of having a representative sample.

Data collection was done through a structured questionnaire that was pre-tested prior to commencement of the full scale survey. Before pre-testing, the questionnaire was also reviewed by experts in international business. The review and pre-testing processes were done in pursuit of content and face validities of the survey instrument. During the data collection, the questionnaires were distributed to the firms' executives and picked by the researcher in person on the agreed date. This approach was deemed more appropriate than mailed survey because Tanzania, like many developing countries, lacks efficient communication infrastructure (Ibeh, 2004).

A total of 122 firm managers completed the questionnaires whose responses were deemed useful for the analysis. Hence, giving an effective response rate of about 49 percent, which is reasonably high for a survey study. The respondent firms have had different socio-economic backgrounds. About 68 firms were exporting to various destinations at the time of survey. Only $25 \%$ of the surveyed firms had foreign connections in terms of ownership as compared to $75 \%$ that were owned by local entrepreneurs. The survey included both small and large firms. About $80 \%$ of the firms were small to medium, having permanently employed less than 100 people. In a Tanzanian context, SMEs are defined as firms with less than 100 employees (URT, 2003). Most firms had been in operation for at least 10 years on the average, whereas only 15 of them had been in business for five years or less. This suggests that the sample comprised firms that had had reasonable experience in business. The study surveyed firms that came from a wide cross-section of the manufacturing industry, producing both consumer and manufacturing goods. Firms in the following industries featured prominently: agro-food processing (26.2\%), Textile and leather (28.5\%), metal (9.8\%), chemical (14.8\%), and handcrafts $(20.5 \%)$.

\subsection{Variables and Measurements}

Export Behavior: Export behavior is the dependent variable of the study. Export behavior has been studied widely using different conceptualization and measurement. For the purpose of this study, export behavior is conceptualized simply as involvement of firms in export activities. Different indicators have been used to operationalize export behavior. Most studies have, however, used either a categorical approach to determine whether or not a firm exports, or export ratio to determine the level (intensity) of export involvement. Those using the categorical approach primarily seek to develop a profile of factors characterizing firms of different export status (Aaby \& Slater, 1989). Nonetheless, measuring export behavior using the categorical approach ignores the fact that firms within each category differ in the degree of export involvement. Subsequently, the current study measures export behavior by export ratio - a proportion of export to total sales-which is advantageous in several ways. First, export ratio has been used extensively, hence, its validity and reliability as a measure of export behavior has well been established (Katsikeas, et al., 2000). Second, apart from measuring export intensity, export ratio has a macroeconomic implication as it is directly related with maximization of a country's exports (Dhanaraj \& Beamish, 2003). Last, most managers are more inclined to provide data related to export sales intensity than data related to profit of firms (Marandu, 2008).

Export barriers: Export barriers were the explanatory variables in the model. The study used perceptual measures of export barriers rather than objective measures. The barrier items used in the current study were 
identified following a review of export management literature. Specifically, the barriers identified in the following studies: Suarez-Ortega (2003), Leonidou (2004), Julian and Ahmed (2005), OECD (2009) and, Pinho and Martins (2010) were considered as suitable for the current study's purpose. The fact that the barriers had already been tested successfully elsewhere, potential threats to validity and reliability of the construct was deemed not serious. To measure the barriers, managers were asked to rate on a five point scale whether a given barrier is having a minor or a major effect on export activities of firms ( $1=$ minor effect; $5=$ major effect).

The barrier items were further subjected to a factor analytical technique in order to identify major barrier factors that could serve as explanatory variables in the regression analysis. Table 1 reports the results. The first group comprised internal barriers labeled export knowledge barriers, capacity barriers, and export financing barriers. The three barrier factors explained about 68.9 percent of the variance. The second group comprised external barriers labeled infrastructure, and regulatory barriers. These barriers explained about 66.2 percent of the variance.

The barrier factors were then subjected to a reliability analysis using Cronbach's alpha coefficient. The alpha coefficients ranged between 0.60 and 0.83 , suggesting that there was adequate internal consistency of items in each of the barrier factor (Hair, et al., 2006). Furthermore, item-to-total correlation analysis was conducted to assess the validity of the factors. All item-to-total correlations were well above 0.70 and significant at a 1 percent level. This suggests that the items loaded into the significant factors are valid and reliable measures of the proposed constructs.

\section{(Insert Table 1 about here)}

\subsection{Modeling Export Behavior of a firm}

The model was designed to take into account the effect of export barrier perceptions on the tendency of a firm to export as measured by export intensity. However, some firms in the sample did not export any of their products. Export intensity assumed a value of zero. Tobit regression model qualified as a technique of analysis because the dependent variable is censored. According to Tobin (1958) and Greene (2003), the general Tobit regression model can be expresses as:

$$
\mathrm{Y}^{*}=\mathrm{X}_{\mathrm{i}}^{\prime} \beta+\mu_{\mathrm{i}}
$$

where $\mathrm{Y}^{*}$ is a latent variable, the dependent variable of interest, $\mathrm{X}$ is a vector of explanatory variables, export barrier factors, $\beta$ is a vector of unknown parameters, and $\mu$ is an independently and normally distributed error term with a zero mean and a constant variance. $\mathrm{Y}^{*}$ being the latent variable is unobservable. For observation above the limit, zero for this matter, the dependent variable is observed as an interval scaled variable. If the observation is on the limit, the dependent variable is assumed to be zero.

A downside of Tobit model is that its slope coefficients measure jointly the effect of an independent variable on the propensity and intensity to export. This adds complexity to the interpretation of the slope coefficients. To solve this problem, McDonald and Moffitt (1980) developed a procedure that decomposes the marginal effect coefficients allowing a straight forward interpretation of the coefficients of export propensity and export intensity. According to McDonald and Moffitt, equation 1 can be expressed in its expected value as:

$$
\mathrm{E}(\mathrm{Y})=\mathrm{F}(\mathrm{z}) \mathrm{E}\left(\mathrm{Y}^{*}\right)
$$

Where $\mathrm{E}(\mathrm{Y})$ is the expected export intensity for the whole sample, $\mathrm{E}\left(\mathrm{Y}^{*}\right)$ is the expected export intensity for current exporters, and $\mathrm{F}(\mathrm{z})$ is the probability of becoming an exporter for potential exporters. The term $\mathrm{F}(\mathrm{z})$ is the cumulative normal distribution function for the proportion of cases above the limit. The partial derivative of equation 2 gives the marginal effect of $\mathrm{E}(\mathrm{Y})$ with respect to $\mathrm{X}$ as follows.

$$
\partial E(Y) / \partial X=F(z)^{\partial E\left(Y^{*}\right)} / \partial X^{+E\left(Y^{*}\right)} \partial F(z) / \partial X
$$

Thus, a change in $\mathrm{E}(\mathrm{Y})$ can be decomposed into: (1) the change in the expected level of export intensity among exporters $\left[\partial \mathrm{E}\left(\mathrm{Y}^{*}\right) / \partial \mathrm{X}\right]$, weighted by the probability of being an exporter, and (2) the change in the cumulative probability of being an exporter, $[\partial F(\mathrm{z}) / \partial \mathrm{X}]$ weighted by the expected level of exporting for current exporters. The term $\partial F(\mathrm{z}) / \partial \mathrm{X}$ indicates the change in the cumulative probability of exporting among potential exporters. Equation 3 can be decomposed further as:

$$
\partial E\left(Y^{*}\right) / \partial X=\beta\left[1-z\left(\frac{f(z)}{F(z)}-\frac{f(z)^{2}}{F(z)^{2}}\right)\right], \text { and } \partial F(z) / \partial X=\beta\left[\frac{f(z)}{\sigma}\right]
$$


Where, $\beta$ is the Tobit coefficient associated with explanatory variables, and $\sigma$ is the standard deviation of the Tobit regression model, often reported alongside other estimated coefficients. The coefficient $\mathrm{z}$ is the $\mathrm{z}$-score for an area under the normal curve and $f(z)$ indicates the value of the derivative of the density function at a given point on the normal curve. The bracketed term, $\partial \mathrm{E}\left(\mathrm{Y}^{*}\right) / \partial \mathrm{X}$, indicates a fraction of the total effect of the explanatory variable, $\mathrm{X}_{\mathrm{i}}$, for firms current exporters. The proportion of the total effect associated with export probability among potential exporters can be obtained by subtracting 1 from the bracketed term. Furthermore, the proportion of the effect that any explanatory variable has on the cases above the limit always remain the same since $F(z), f(z)$ and $z$ remain the same for a particular Tobit estimation (Pradhan, 2004).

\section{Results and Discussions}

Table 2 reports descriptive statistics, correlation matrix and VIF scores for the variables used in the analysis. All export barrier factors have a mean score above 3 , suggesting that on average managers considered these barriers as having major effect on export activities of firms. The correlations between most explanatory variables were not strong. All the correlation coefficients were below 0.50 , except for knowledge and regulatory barriers. To test for the potential threat of multicollinearity, VIF scores were computed, and the scores for all variables were below 2. Therefore, multicollinearity can be ruled out as a serious problem in this study (Hair, et al., 2006).

\section{Insert Table 2 about here}

\subsection{Regression Analysis}

Table 3 reports the results of the Tobit model estimation. The second, third and fourth columns in the table show the latent Tobit coefficients, standard errors and significance level, respectively. The two columns under the heading marginal coefficients report the McDonald and Moffitt's decomposition coefficients. The last column reports the standardized coefficients of the Tobit model. The results show that all the coefficients have negative signs and hence, conforming to a priori expectation. Three of the barrier factors: export knowledge $(\beta=-0.150$; $\mathrm{p}<0.000)$, export financing $(\beta=-0.055 ; \mathrm{p}<0.044)$, and infrastructure $(\beta=-0.073 ; \mathrm{p}<0.010)$ were the primary determinants of export behavior. These barriers came up statistically significant at a 5 percent level.

\section{Insert Table 3 about here}

The marginal effect coefficients offer useful and straightforward interpretation of the magnitude of the effects. The coefficient of export knowledge and information barriers suggests that a point scale increase in export knowledge/information barrier perception results in a 0.085 decrease in export intensity among exporting firms, and a 0.203 decrease in the likelihood of exporting among non-exporting firms, all else being equal. This finding signifies the criticality of export market knowledge and information in the export decision process. Naturally, with relevant export market knowledge and accurate information, firms can formulate competitive export strategies and, circumvent foreign market risks and uncertainties. In Tanzania, the market for information is limited, communication is difficult and the communication infrastructure is underdeveloped (URT, 2003). Therefore, the significance of export knowledge and information barriers in this setting makes sense. Moreover, the results apparently confirm earlier research's findings and supports existing theories of export behavior. For example, studies (OECD, 2009; Okpara \& Koumbiadis, 2009; Pinho \& Martins, 2010) show that the lack of export knowledge and information is the top most barrier to exporting.

Export financing is another significant variable in the model. The marginal effect coefficients suggest that, all else being equal, a point scale increase in financing barrier perception results in a 0.031 reduction in export intensity among exporting firms and a 0.074 decrease in the probability of exporting among non-exporting firms. Essentially, the results support the notion that a firm with limited financial resources is less likely to be competitive abroad. This is because, firstly, export activity involves deferred payments whose times tend to be longer than domestic trade (Ling-yee \& Ogunmokun, 2001). In the intervening period, firms must be in a sound financial position in order to sustain their business activities. Secondly, export activity is a venture which requires financial resources for its successful implementation and sustenance. Thus, a firm needs to have sufficient amount of funds to be able to enhance production capacity, develop skills of export personnel, and meet other operational costs (Tannous, 1997; Ling-Yee \& Ogunmokun, 2001). Lastly, adequate financial resources are also required for insurance against such export related risks as transport hazards, currency volatility and non-compliance of foreign business partners (Uexkull, 2006).

Regarding exogenous barriers, the perceived poor infrastructure emerged particularly important in explaining export behavior. The variable was statistically significant at the 0.05 level. The marginal effect coefficients suggest that a point scale increase in the infrastructural barrier perceptions results into a 0.041 decrease in the level of export intensity by exporters and a 0.099 decrease in the probability of exporting by potential exporters, 
all else equal. The variable was made up of two items - transport and communication, and utility supply. Understandably, transport can make it difficult and costly to move goods from one point to another within and outside the country, adding up to the costs of the product. As Kweka (2006) suggests, transport cost is equivalent to export tax which tend to slow down export supply responsiveness. The significance of infrastructural barriers makes sense and generally supports earlier findings in the area. For example, Bank of Tanzania (BOT)(2001) indicates that unreliability and high cost of utility supply as well as poor road and distribution networks remain a burden to the firms' export competitiveness.

\subsection{Assessing the Strength of Export Barriers}

In this section, the relative strength of individual export barriers is analyzed. According to Pradhan (2004), the relative strength can be assessed by using the standardized coefficients and the marginal coefficients. This analysis is relevant for policy makers and managers because it helps to identify top most barriers and to determine where the bulk of their effect lies such as on export probability or on the level of export intensity.

The standardized Tobit coefficients reported in Table 3 suggest that the lack of export knowledge and information is the strongest predictor of export performance. The absolute standardized coefficient of this variable is 0.399 , which is the largest. This echoes the findings of previous studies that found that the lack of export market knowledge and information tend to have very high impact on export activities of firms (e.g. Leonidou, 2004; OECD, 2009). Other barriers - infrastructure and export financing barriers - can be ranked second and third, with the coefficients of 0.219 and 0.178 , respectively. The two barriers reflect the stringent nature of the business environment facing Tanzanian firms.

It is also interesting to note that the effect of export barriers falls disproportionately on the export behavior. Diving marginal effect coefficients by the latent Tobit coefficient, it was noted that about 57 percent of the effect fell on the level of export intensity whereas about 43 percent fell on the probability of exporting. This implies that any effort to reduce export barriers would be felt more by current exporters who would be encouraged to expand export activities. Apparently, the findings support the contention that export barriers are felt disproportionately at different levels of export involvement (Suarez-Ortega, 2003).

\section{Conclusion and Implications}

The study examined export marketing barriers, and determined their impact on export performance of firms in Tanzania, an underdeveloped country. The study aimed to address the gap in the literature and contribute knowledge in the following ways. Firstly, the study provides empirical evidence on the extent to which export barriers affect export activities of firms. In pursuing this objective, the study identified important barriers and determined their relative strength. The Tobit model facilitates the analysis of the relative contribution of individual barriers to export performance. Lastly, the setting of the research provides an insight into validity and reliability of previous research's conclusions. The study has been conducted in a developing country setting, the area where empirical evidence on firms' export behavior is limitedly available.

The underlying hypothesis of the study was that stronger export barrier perceptions negatively affect export performance. The barriers identified in the current study namely, lack of export knowledge and information, lack of export supply capacity, lack of export financing, poor infrastructure and regulatory barriers, are in many ways similar to those identified elsewhere. This seems to suggest that the barriers are universal. In analyzing the effect of barriers on export behavior, it was found that when barriers are felt strongly, there was a low probability of exporting among potential exporters and a low level of export intensity among current exporters. The findings clearly support the hypothesis of the study and confirm the notion that export barriers tend to dissuade firms from exporting (Leonidou, 2004). Interestingly, however, the effects of the barriers differed markedly in strength suggesting that the barriers have disproportionate effect. For example, the bulk of the effect of the barriers had been felt on the export intensity. Therefore, current exporters tend to be more responsive to a change in export barriers compared to their counterpart. Probably, these managers are more risk averse. Moreover, comparing the effect of individual barriers, the lack of export knowledge and information was ranked the strongest barrier followed by the lack of export financing, and poor infrastructure.

Several implications can be drawn from these findings. Based on the findings, policy makers should understand specific barriers and policy interventions required to enhance export performance. For example, although financial sector reforms had been scaled up in the wake of trade liberalization, the current findings suggest that financial constraints still hamper export activities of the Tanzanian firms. Similarly, while several business supporting institutions exist in Tanzania, the lack of export knowledge and information is still a major problem. Therefore, strong commitment to institutional reforms should be intensified. Furthermore, the government 
should continue to invest in infrastructure because currently poor transport and distribution networks greatly increase operational costs and hamper smooth export supply responses (Kweka, 2006).

The findings have important implications for managers. Firstly, managers should be aware that venturing into overseas markets is not trouble free, because different kinds of barriers stand on their way (Leonidou, 2004). Hence, adequate preparations and efforts to minimize the barriers are needed. In the context of this study, managers should be aware of the potential detrimental effects that the lack of export market knowledge and information, the lack of export financing, and poor infrastructure could bring to their firms. In effect, managers need to develop positive attitudes towards exporting and be pro-active in searching for information and other export assistance. For example, the available export guarantee schemes, trade fairs and export processing zones should be fully exploited by firms.

Secondly, business supporting institutions in Tanzania work inefficiently (SME Competitive Facility - SCF, 2006), hence, affecting access to critical business development services. While it takes time to build efficient institutions, managers should fully exploit the available networks of personal contacts. As Rutashobya and Jaesson (2004) indicate, Tanzanian firms can overcome internationalization barriers through social networking. In addition, internet offers a platform for learning about market opportunities, for marketing products and for building relationships with oversees partners. Indeed, the advent of internet and its subsequent adoption have greatly helped firms to overcome most export marketing hurdles (Prashantham \& Young, 2004). Therefore, managers should make use of internet facilities for communication, market intelligence and export promotion.

Finally, the findings in the present study should be interpreted in the light of a number of limitations. One, though the analytical technique suggests that export barriers affect export behavior, the cross sectional nature of the study's design poses challenges to the validity of a causal interpretation. A longitudinal design is more appropriate for solving this problem. Two, the findings are country specific, hence may lack external validity given that developing countries are as heterogeneous as their firms. Three, the study investigated export barriers regardless of the markets that firms entered or planned to enter. The fact that different markets have different characteristics, suggest that understanding barriers within specific market contexts is imperative. Future studies should examine barriers to exporting in specific regional markets such as within East Africa, sub-Saharan Africa, Asia, and the EU.

\section{References}

Aaby, N., \& Slater, S. F. (1989). Management influences on export performance: A review of the empirical literature 1978 - 1988. International Marketing Review, $6(4): \quad 53 \quad-\quad 68$. http://dx.doi.org/10.1108/EUM0000000001516

Anderson, W. (2011). Internationalization opportunities and challenges for small and medium-sized enterprises from developing countries. Journal of African Business, 12 (2): 198-217. http://dx.doi.org/10.1080/15228916.2011.588912

Arteaga-Ortiz, J., \& Fernandez-Ortiz, R. (2010). Why don't we use the same export barrier measurement scale? an empirical analysis in small and medium-sized enterprises. Journal of Small Business Management, 48(3): 395-420. http://dx.doi.org/10.1111/j.1540-627X.2010.00300.x

BOT. (2001). Tanzania investment report. Report on the study of foreign private capital flows in mainland Tanzania. Dar es Salaam, Bank of Tanzania: 1-131.

Bigsten, A., \& Danielson, A. (2001). Tanzania: Is the ugly duckling finally growing up? A Report for OECD Project "Emerging Africa". Uppsala, Nordiska Afrikainstitute.

Blomstermo, A., Eriksson, K., \& Sharma, D. (2004). Domestic activity and knowledge development in the internationalization process of firms. Journal of International Entrepreneurship, 2: 239-258. http://dx.doi.org/10.1023/B:JIEN.0000032775.53005.59

CTI (2003). Report on Small and Medium Enterprises (SMEs) in Tanzania. Dar es Salaam, prepared by Iramba Management and Industries Services Ltd.

da Silva, P. A., \& da Rocha, A. (2001). Perception of export barriers to Mercosur by Brazilian firms. International Marketing Review, 18(6): 589-610. http://dx.doi.org/10.1108/EUM0000000006296

Dhanaraj, C., \& Beamish, P. W. (2003). A resource-based approach to the study of export performance. Journal of Small Business Management, 41(3): 242-261. http://dx.doi.org/10.1111/1540-627X.00080 
Ghauri, P., Lutz, C., \& Tesfom, G. (2003). Using networks to solve export-marketing problems of small and medium-sized firms from developing countries. European Journal of Marketing, 37(5/6), 728-752. http://dx.doi.org/10.1108/03090560310465125

Greene, W. H. (2003). Econometric analysis. New Jersey, Prentice Hall.

Hair, J. H., \& W. C. Black, et al. (2006). Multivariate data analysis. Upper Saddle River-New Jersey., Pearson Prentice Hall

Ibeh, K. I. L. (2004). Furthering export participation in less performing developing countries: the effects of entrepreneurial orientation and managerial capacity factors. International Journal of Social Economics, 31(1/2): 94-110. http://dx.doi.org/10.1108/03068290410515448

Julian, C. C., \& Ahmed, Z. U. (2005). The impacts of barriers to export on export marketing performance. Journal of Global Marketing, 19 (1): 71-9. http://dx.doi.org/10.1300/J042v19n01_05

Katsikeas, C. S., Leonidou, L. C., \& Morgan, N. A. (2000). Firm-level export performance assessment: review, evaluation and development. Journal of the Academy of Marketing Science, 28 (4): 493-511. http://dx.doi.org/10.1177/0092070300284003

Korneliussen, T., \& Blasius J. (2008). The effects of cultural distance, Free Trade Agreements, and Protectionism on perceived export barriers. Journal of Global Marketing, 21(3): 217-230. http://dx.doi.org/10,1080/08911760802152074

Kweka, J. (2006). Trade policy and transport costs in Tanzania. CREDIT Research paper 06/10. Nottingham, Nottingham University: 1-33. [Online] Available: www.nottingham.ac.uk/economics/credit/ (January, 2010)

Leonidou, L. C. (2004). An analysis of barriers hindering small business export development. Journal of Small Business Management, 42 (3): 279-302. http://dx.doi.org/10.1111/j.1540-627X.2004.00112.x

Limao, N., \& Venables A. J. (2001). Infrastructure, geographical disadvantage, transport costs and trade. World Bank Economic Review, 15(2001): 451-479. http://dx.doi.org/10.1093/wber/15.3.451

Ling-Yee, L., \& Ogunmokun, G. O. (2001). Effect of Export Financing Resources and Supply Chain Skills on Export Competitive Advantage: Implication for Superior Export Performance. Journal of Business, 36(3): 260-279.

Marandu, E. E. (2008). Strategy factors associated with the export performance of manufacturing firms. The Journal of Business in Developing Nations, 11(2008-2009): 33-76.

McDonald, J. F., \& Moffitt R. A. (1980). The uses of Tobit analysis. The Review of Economics and Statistics, 62: $318-821$.

Milner, C., \& Tandrayen V. (2007). The impact of exporting and export destination on manufacturing wages: evidence for sub-Saharan Africa. Review of Development Economics, 11(1): 13-30. http://dx.doi.org/10.1111/j.1467-9361.2006.00353.x

Naidu, G. M., \& Rao, T. R. (1993). Public sector promotion of exports: a need based approach. Journal of Business Research, 27: 85 - 101. http://dx.doi.org/10.1016/0148-2963(93)90017-J

OECD (2009). Top barriers and drivers of SME internationalization. Report by the OECD working party on SMEs and Entrepreneurship: 1-32.

Okpara, J. O., \& Koumbiadis, N. J. (2009). Strategic export orientation and internationalization barriers: evidence from SMEs in a developing economy. Journal of International Business and Cultural Studies, 1: 1-10.

Pinho, C. J., \& Martins, L. (2010). Exporting barriers: insights from Portuguese small-and medium- sized exporters and non-exporters. Journal of International Entrepreneurship, 8(2010): 254-272. http://dx.doi.org/10.1007/s10843-010-0046-x

Pradhan, J. P. (2004). The determinants of outward foreign direct investment: a firm-level analysis of Indian $\begin{array}{lllll}\text { manufacturing firms. } & \text { Oxford Development } & \text { Studies, } & \text { 32(4): }\end{array}$ http://dx.doi.org/10.1080/1360081042000293371

Prashantham, S., \& Young, S. (2004). The Internet and the Internationalization of Small Knowledge-Intensive Firms: Promises, Problems, and Prospects, University of Strathclyde International Business Unit. Glasgow: University of Strathclyde.

Rankin, N., \& M. Soderbom, et al. (2006). Exporting from Manufacturing Firms in Sub-Saharan Africa. Journal of African Economies, 15(4): 671-687. http://dx.doi.org/10.1093/jae/ejk014 
Rutashobya, L., \& Jaensson, J. (2004). Small firms' internationalization in Tanzania: exploring the network phenomenon. International Journal of Social Economics, 31(1/2): 159-172. $\mathrm{http}: / / \mathrm{dx}$. doi.org/10.1108/03068290410515484

SCF. (2006). SME Export Market Prospects Desk Study. Dar es Salaam, SME Competitive Facility.

Suerez-Ortega, S. (2003). Export barriers: insights from Small and Medium-sized firms. International Small Business Journal, 21(4): 403-419. http://dx.doi.org/10.1177/02662426030214002

Tannous, D. G. (1997). Financing export activities of small Canadian businesses: exploring the constraints and possible solution. International Business Review, 6(4): 411-431. http://dx.doi.org/10.1016/S0969-5931(97)00012-7

Tobin, J. (1958). Estimation of relationships for limited dependent variables. Econometrica, 26: 24 - 36.

Uexkull, E. (2006). Identifying financial constraints under trade liberalization: lesson from Kenya, Uganda and Ghana. Discussion Paper (1/2006). German Development Institute.

URT (2003). Trade and Development Policy. Dar es Salaam, Ministry of Trade and Industry.

URT (2008). The Economic Survey 2007. Dar es Salaam, Ministry of Finance and Economic Affairs.

van Biesebroeck, J. (2005). Exporting raises productivity in sub-Saharan African manufacturing firms. Journal of International Economics, 67: 373-391. http://dx.doi.org/10.1016/j.jinteco.2004.12.002

World Bank. (2004). Improving Enterprise Performance and Growth in Tanzania. Investment Climate Assessment. Washington, World Bank and International Finance Corporation: 5-115.

Wright, M., \& I. Filatotchev, et al. (2005). Strategy research in emerging economies: challenging the conventional wisdom. Journal of Management Studies, 42(1): 1-33. 
Table 1. Factor Analysis of Export Barriers

\begin{tabular}{|c|c|c|c|c|c|c|c|}
\hline A: Internal Barriers & Mean & $\begin{array}{l}\text { Std. } \\
\text { Dev. }\end{array}$ & $\begin{array}{c}\text { Knowledge } \\
\text { Barriers }\end{array}$ & $\begin{array}{l}\text { Capacity } \\
\text { Barriers }\end{array}$ & $\begin{array}{c}\text { Financing } \\
\text { Barriers }\end{array}$ & $\begin{array}{l}\text { Infrastr. } \\
\text { Barriers }\end{array}$ & $\begin{array}{c}\text { Regulatory } \\
\text { Barriers }\end{array}$ \\
\hline $\begin{array}{l}\text { Lack of knowledge about } \\
\text { foreign business practices }\end{array}$ & 3.35 & 1.29 & 0.79 & & & & \\
\hline $\begin{array}{l}\text { Lack of knowledge about } \\
\text { export market opportunities }\end{array}$ & 3.33 & 1.26 & 0.89 & & & & \\
\hline $\begin{array}{l}\text { Difficulties in } \\
\text { communicating with foreign } \\
\text { customers/distributors }\end{array}$ & 3.24 & 1.17 & 0.67 & & & & \\
\hline $\begin{array}{l}\text { Lack of information on the } \\
\text { available export support } \\
\text { programs }\end{array}$ & 3.52 & 1.21 & 0.81 & & & & \\
\hline $\begin{array}{l}\text { Inability to offer goods at } \\
\text { competitive price }\end{array}$ & 3.56 & 1.34 & 0.55 & & & & \\
\hline $\begin{array}{l}\text { Export supply capacity } \\
\text { constraints }\end{array}$ & 3.09 & 1.30 & & 0.82 & & & \\
\hline $\begin{array}{l}\text { Inability to meet export } \\
\text { requirements (quality, } \\
\text { design \& styles) }\end{array}$ & 3.01 & 1.30 & & 0.88 & & & \\
\hline $\begin{array}{l}\text { Lack of skills of available } \\
\text { staff }\end{array}$ & 3.54 & 1.22 & & 0.55 & & & \\
\hline Lack of financial resources & 3.98 & 1.28 & & & 0.85 & & \\
\hline $\begin{array}{l}\text { Limited access to export } \\
\text { financing }\end{array}$ & 3.79 & 1.28 & & & 0.87 & & \\
\hline $\begin{array}{l}\text { B: External Barriers } \\
\text { Poor transp. and comm. } \\
\text { Infrastructure }\end{array}$ & 3.27 & 1.16 & & & & 0.88 & \\
\hline $\begin{array}{l}\text { Unreliable and costly } \\
\text { power/energy supply }\end{array}$ & 3.48 & 1.21 & & & & 0.90 & \\
\hline Home tax administration & 3.99 & 1.06 & & & & & 0.62 \\
\hline Lack of government support & 3.75 & 1.15 & & & & & 0.78 \\
\hline $\begin{array}{l}\text { Cumbersome domestic } \\
\text { export procedures }\end{array}$ & 3.61 & 1.03 & & & & & 0.80 \\
\hline Eigen values & & & 4.25 & 1.63 & 1.00 & 2.08 & 1.23 \\
\hline Variance explained (\%) & & & 42.5 & 16.4 & 10.0 & 41.6 & 24.6 \\
\hline Cronbach's alpha & & & 0.83 & 0.77 & 0.83 & 0.76 & 0.60 \\
\hline
\end{tabular}

Table 2. Correlation Matrix and Summary Statistics

\begin{tabular}{|l|l|cccccc|}
\hline & & 1 & 2 & 3 & 4 & 5 & 6 \\
\hline 1. & Export behavior & 1.00 & & & & & \\
2. & Knowledge/information barriers & $-0.48^{*}$ & 1.00 & & & & \\
3. & Capacity barriers & $-0.31^{*}$ & $0.40^{*}$ & 1.00 & & & \\
4. & Financial barriers & $-0.35^{*}$ & $0.37^{*}$ & $0.49^{*}$ & 1.00 & & \\
5. & Infrastructure barriers & 0.00 & -0.10 & -0.16 & $-.37^{*}$ & 1.00 & \\
6. & Regulatory barriers & $-0.38^{*}$ & $0.57^{*}$ & $0.33^{*}$ & $0.47^{*}$ & $-0.23^{*}$ & 1.00 \\
& Mean & 0.17 & 3.40 & 3.22 & 3.88 & 3.38 & 3.78 \\
& Std deviation & 0.23 & 0.97 & 1.05 & 1.19 & 1.09 & 0.81 \\
& VIF & & 1.62 & 1.43 & 1.69 & 1.69 & 1.17 \\
\hline
\end{tabular}

*Significant at $5 \%$ level 
Table 3. Tobit Estimation of Export Performance

\begin{tabular}{|c|c|c|c|c|c|c|}
\hline \multirow[b]{2}{*}{ Explanatory Variables } & \multicolumn{3}{|c|}{$\begin{array}{l}\text { Dependent Variable: Export } \\
\text { Performance }\end{array}$} & \multicolumn{2}{|c|}{ Marginal Effects } & \multirow{2}{*}{$\begin{array}{c}\text { Fully } \\
\text { Stdized. } \\
\text { Coeff. }\end{array}$} \\
\hline & Coeff. & $\begin{array}{l}\text { Std. } \\
\text { Error }\end{array}$ & $p$-value & $\begin{array}{l}\text { Export } \\
\text { intensity }\end{array}$ & $\begin{array}{c}\text { Export } \\
\text { probability }\end{array}$ & \\
\hline Export knowledge barriers & -0.150 & 0.039 & 0.000 & -0.085 & -0.203 & -0.3994 \\
\hline Export supply capacity barriers & -0.033 & 0.035 & 0.353 & -0.019 & -0.045 & -0.0955 \\
\hline Export financing barriers & -0.055 & 0.032 & 0.044 & -0.031 & -0.074 & -0.1786 \\
\hline Regulatory barriers & -0.041 & 0.047 & 0.383 & -0.023 & -0.055 & -0.0903 \\
\hline Infrastructure barriers & -0.073 & 0.031 & 0.010 & -0.041 & -0.099 & -0.2196 \\
\hline Constant & 1.216 & 0.200 & 0.000 & & & \\
\hline Sigma & 0.292 & 0.027 & & & & \\
\hline Observations & 122 & & & & & \\
\hline Pseudo $\mathrm{R}^{2}$ & 0.335 & & & & & \\
\hline
\end{tabular}

